\title{
Does team psychological capital predict team outcomes at work?
}

\author{
Lea Waters · Gabriel Strauss · Anit Somech · Nick Haslam · Denise Dussert
}

\begin{abstract}
This study is situated in the paradigms of positive organizational scholarship (POS) and positive organizational behaviour (POB). It draws upon the theoretical mechanisms of social learning and emotional contagion to suggest that psychological capital may spread through work teams to impact team outcomes such as performance, innovation, and organizational citizenship behavior (OCB). The degree to which team psychological capital (TPsyCap) mediated the relationship between leader psychological capital (LPsyCap) and team outcomes was also tested ( $\mathrm{n}=94$ teams; $\mathrm{n}=94$ leaders; $\mathrm{n}=550$ employees). Using structural equation modelling, LPsyCap and TPsyCap were both related to team-level organizational citizenship behavior, team performance, and team innovation. However, the relationship between LPsyCap and TPsyCap was not significant. These findings support the positioning of psychological capital as an important resource for optimal team functioning but also suggest that workplaces cannot expect that leaders, through their own psychological capital alone, can create team-level psychological capital. Instead, the current research suggests that other organizational initiatives and experiences are needed to enhance LPsyCap. The results contribute to a better understanding of POS and POB in general and, specifically, to the recently emerging construct of team psychological capital.
\end{abstract}

Keywords: Psychological capital, teams, leadership, positive organizational behavior, positive psychology

\section{Introduction}

Workplace teams are social groups whose members interact interdependently to achieve shared goals (Devine, Clayton, Philips, Dunford, \& Melner, 1999; Salas, Cooke, \& Rosen, 2008). Teams are now commonplace within organizations across diverse sectors (Tannenbaum, Mathieu, Salas, \& Cohen, 2012; West, Patera \& Carsten, 2009), making research into how teams operate an important area of inquiry. Leadership is one factor that plays an important role in team functioning (Al Rahbi, Khalizani \& Mehmood, 2017; Bandura, 1997; DeChurch, Hiller, Murase, Doty \& Salas, 2010). Zaccaro, Blair, Peterson and Zazanis (1995) argue that the central role of leadership is "fusing a capable team from disparate individuals and building perceptions among individual members of their combined and collective abilities" (p. 317). One way that leadership may impact on team outcomes is through the influence of a leader's psychological capital (PsyCap), described as a positive psychological state of development (Luthans, Avolio, Avey, \& Norman, 2007) that is characterized by having high levels of HERO: Hope, (Self-)Efficacy, Resilience, and Optimism 
(Luthans, Youseff, \& Avolio, 2007a). The PsyCap of leaders has been shown to influence the PsyCap of his/her followers (Chen, 2015; Chen, Wen, Kong, Niu \& Hau, 2017), but to date, research has not investigated if leader psychological capital (LPsyCap) is associated with team-level psychological capital (TPsyCap) and team outcomes.

The current study extends research on psychological capital by examining the relationship between LPsyCap, TPsyCap, and three team-level outcomes: team performance, team innovation, and team organizational citizenship behavior (OCB). The degree to which TPsyCap mediates the relationship between LPsyCap and the three team outcomes will also be examined.

\section{Psychological Capital}

Conceptualised as a higher-order construct, PsyCap represents the shared variance of four constructs: hope, efficacy, resilience, and optimism (Avey, Luthans, \& Jensen, 2009; Avey, Luthans, \& Youssef, 2010; Luthans, Avolio, Avey, \& Norman, 2007). Taken from the work of Snyder et al. (1991), hope is defined as a "motivational state that is based on an interactively derived sense of successful (1) agency (goal-directed energy) and (2) pathways (planning to meet goals)" (p. 287). Drawing from the work of Bandura (1997), self-efficacy is defined as a person's "conviction (or confidence) about his or her abilities to mobilise the motivation, cognitive resources, or courses of action needed to successfully execute a specific task within a given context" (Stadjkovic, Luthans, \& Slocum, 1998, p. 66). Masten and Reed (2002) defined resilience as "a class of phenomena characterized by patterns of positive adaptation in the context of significant adversity or risk" ( $\mathrm{p}$. 74). Similarly, Luthans (2002) defines resilience as the "capacity to rebound or bounce back from adversity, conflict, failure, or even positive events, progress, and increased responsibility" (p. 702). The definition of optimism is taken both from the work of Scheier and Carver (1985) and of Seligman (1990). Scheier and Carver (1985) conceptualised optimism as a positive future expectation. Seligman (1990) defined optimism as an explanatory or attributional style. An optimistic person attributes negative events to external, temporary, and situation-specific causes, and positive events to personal, permanent, and pervasive causes.

Williams, Kern and Waters (2016) describe PsyCap as a 'resource bank' that enables adaptive responses to challenges, builds successful performance, and fosters high wellbeing. Indeed, research has consistently shown the benefits to individuals who have, or develop, their PsyCap in multiple life domains, including relationships, physical health, and work (Hobfoll, 2002; Lyubomirsky, Sheldon \& Schkade, 2005).

In the workplace, PsyCap has also been found to be a particularly useful resource (Paterson, Luthans, \& Jeung, 2014). Hsu, Wang, Chen and Dahlgaard-Park (2014) posit that the heightened sense of agency experienced with high PsyCap motivates employees to show stronger persistence towards goals, have higher task accomplishment, and remain optimistic when facing setbacks. Williams, Kern and Waters (2015) showed that PsyCap was a significant predictor of work happiness in teachers and school staff (e.g., administrative staff, IT staff, support staff) and that this relationship persisted over time (Williams, Kern \& Waters, 2017). PsyCap has been empirically linked to a number of other desirable employee outcomes such as higher job satisfaction (Luthans, Avolio, Avey, \& Norman 2007; Abbas, Raja, Darr, \& Bouckenooghe, 2014), organizational commitment (Jensen and Luthans, 2006), psychological wellbeing (Avey, Luthans \& Youssef, 2010), 
thriving (Paterson et al., 2014), job performance (Abbas et al., 2014), and job embeddedness (Sun, Zhao, Yang, \& Fan, 2012) across industries such as telecommunication, banks, nursing, and textile manufacturing.

Importantly, research shows that an individual's level of PsyCap can be increased through PsyCap workplace training programs (Luthans, Avey, \& Patera, 2008; Williams et al., 2016). In addition to training, another factor that shapes an employee's PsyCap is the PsyCap of the leader (LPsyCap). For example, Avey and colleagues found that the PsyCap of managers was positively related to followers' PsyCap in two separate experimental studies examining engineers and senior employees (Avey, Avolio \& Luthans, 2011; Avey, Richmond, \& Nixon, 2012). In teams of matched leader-followers ( $n=60$ leaders $/ n=319$ employees) at a telecommunications company Chen (2015) found that leaders' PsyCap was a significant predictor of follower PsyCap together with followers' job engagement. Similarly, Walumbwa, Peterson, Avolio, and Hartnell (2010) showed that the psychological capital of police lieutenants was positively related to the psychological capital of their followers. Finally, Chen et al. (2017) found a relationship between LPsyCap and follower PsyCap in their study across three financial companies.

\section{PsyCap as a Group-level Construct}

Although PsyCap was initially conceptualized as an individual resource, recent work suggests it can also be a group phenomenon. Indeed, each of the HERO constructs forming PsyCap have been shown to be applicable at the collective level. For example, Braithwaite (2004) defines collective hope as "hope that is genuinely and critically shared by a group" (p. 7), and Bar Tel (2001) suggests that hope can be a collective emotion, orientation, and action. Benet, Aden, Broome, Mitchell, and Rigdon (2010) assert that "resilience may be viewed as much as a social factor (existing in teams or groups) as an individual trait" (p. 225). Likewise, West, Patera, and Carsten (2009) investigated resilience at the team level, defining it as the team's capacity to bounce back from failure, setbacks, and threats to wellbeing. They found a significant, positive relationship between team resilience and team satisfaction, as well as a significant, negative relationship between team resilience and team conflict. Other researchers have shown that team resilience is linked to team performance and adaptive team responses (Carmeli, Friedman \& Tishler, 2013; Salanova, Llorens, Cifre, \& Martínez, 2012). In Bandura's (1997b) work on self-efficacy he proposed that it was not only an individual state but also a collective property, suggesting that "collective efficacy represents a group's shared belief in its conjoint capabilities to organize and execute the courses of action required to produce given levels of attainments" (p. 477). Similarly, Prussia and Kinicki (1996) defined collective efficacy as “perceptions regarding a team's capability to perform in a particular situation" (p. 188). Collective efficacy has been found to be a predictor of group performance in sporting teams (Spink, 1990; Watson, Chemers \& Preiser, 2001), high school teams (Hodges \& Carron, 1992), as well as in undergraduate students engaging in brainstorming tasks and model construction (Prussia \& Kinicki, 1996; Silver \& Bufanio, 1996). Finally, optimism has also been conceptualised as moving beyond the individual with Anglin, Mckenny and Short (2018) defining collective optimism as "the shared, positive expectations about future outcomes" (p. 390). Research shows that collective optimism influences executives' willingness to make strategic acquisitions (Gao, 2010), consumer behavior (Ludvigson, 2004), and new venture creation for entrepreneurs (Anglin et al., 2018), and is 
positively related to satisfaction, resilience, and cohesion in undergraduate work teams (West et al., 2009).

As discussed above, PyCap is conceptualised as a higher-order construct that represents the shared variance of hope, efficacy, resilience, and optimism. Hence, while research shows that each of the individual elements of PsyCap can be conceptualized at the collective level, Dawkins, Martin, Scott, and Sanderson (2015) also suggest that PsyCap itself (i.e., the shared variance of each of the four elements) can be experienced at the collective level. Dawkins et al. (2015) drew on the principle of social contagion to explain how PsyCap becomes a collective state through its spread from person to person (i.e., social networks) (Christakis \& Fowler, 2013) and via imitation (Bandura, Ross, \& Ross, 1961; Ogunlade, 1979).

Heled, Somech, and Waters (2016) suggest that collective PsyCap occurs via the mechanism of shared mental models, reasoning that, over time, teams develop common ideas and understandings about how they operate (i.e., how to organize their knowledge, tasks, capabilities and goals) and who they are (i.e., we are a loyal team, we are a creative team, we are a competitive team). In line with this, Heled et al. (2016) suggested that shared mental models can be formed about the degree to which the team sees itself as hopeful, efficacious, resilient, and optimistic.

Heled et al.'s (2016) theory of shared mental models is consistent with Peterson and Zhang's (2011) definition of collective PsyCap as "the team's shared (italics added) positive appraisal of their circumstances and probability for success under those circumstances based on their combined motivated effort and perseverance" (p. 134). It also aligns with the definition of collective PsyCap put forward by Dawkins et al. (2015) as "a sense of sharedness among team members regarding their perceptions of PsyCap" (p. 929). Interestingly, Dawkins and her colleagues (2105) propose that there is more than one type of collective PsyCap and propose five distinct forms: summated PsyCap, assimilated PsyCap, team PsyCap, PsyCap strength, and team PsyCap strength.

The focus of the current study is team psychological capital (TPsyCap). TPsyCap differs from individual and other forms of collective PsyCap because it accommodates the fact that individual team members may have low PsyCap yet still perceive the PsyCap of their team to be high (Chan, 1998), or have high individual PsyCap but be in a team that has a shared perception of low collective capital.

TPsyCap is measured using a referent shift composition model that asks members of the team about the perceived PsyCap they see in the team as a whole. Within-team agreement is then examined, and if there is sufficient consistency, scores are aggregated to yield a single team-level value. Several studies have supported the empirical coherence of such measures of TPsyCap (ClappSmith, Vogelgesang, \& Avey, 2009; Walumbwa et al., 2010; West, Patera, \& Carsten, 2009).

Give the recency of the TPsyCap construct, empirical research is still in its infancy, but the small amount that has been conducted shows that TPsyCap, like individual PsyCap, is beneficial in workplaces. Heled et al. (2016) found a significant relationship between TPsyCap, employee job satisfaction, and team level organizational citizenship behavior (OCB). Mathe-Soulek, Scott-Halsell, Kim, and Krawczyk (2014) found that it significantly predicted service quality, customer satisfaction, and unit revenues across 67 food retail chain stores. Although limited, the nascent research on TPsyCap indicates that it is a workplace asset worth cultivating. Thus, the question arises, how can TPsyCap be fostered? 


\section{Does Leader PsyCap influence TPsyCap?}

As outlined above, several studies have demonstrated the influence of leaders' PsyCap (LPsyCap) on their followers' individual PsyCap (Avey, Avolio \& Luthans, 2011; Avey, Richmond \& Nixon, 2012; Chen, 2015; Chen, et al., 2017). To date the relationship between a leader's psychological capital and TPsyCap has not been examined, but the recent research interest on PsyCap as a collective asset, together with the preliminary findings that TPsyCap fosters positive workplace outcomes, makes the relationship between LPsyCap and TPsyCap a promising area of inquiry. In the current study we hypothesize that the PsyCap of a leader will significantly influence a team's shared positive appraisal of their circumstances and probability for success (i.e., TPsyCap), and we posit two mechanisms through which the LPsyCap-TPsyCap relationship is likely to occur: social learning and emotional contagion.

According to Bandura's (1977a, b) social learning theory, individuals learn by attending to and observing the behavior of others, especially credible role models. In organizations, leaders generally have higher status and power than their followers and, thus, are influential models for their employees (Walumbwa et al., 2010). As such, leaders' hopeful, optimistic, resilient, and selfefficacious behaviors may potentially be observed and modelled by team members. Team-level PsyCap occurs when there are consistent perceptions across team members of the psychological capital demonstrated by their teammates. Since each team member models the same leader's psychological capital, it is likely that the level of psychological capital across members becomes aligned over time. This consistency among individual team members' PsyCap is likely to lead to agreement among team members on the shared PsyCap of the team, thus leading to team-level PsyCap that is similar to that of the leader.

Emotional contagion may also play a role in the transferal of PsyCap from leaders to teams. Emotional contagion refers to "the process by which the emotions expressed by one individual are 'caught' by another" (Bono \& Ilies, 2006, p. 320). This occurs because people tend to mimic others' public displays of mood, which then leads them to experience corresponding emotions (Hatfield, Cacioppo, \& Rapson, 1994). Sy, Cote, and Saavedra (2005) argued that this effect is particularly strong between leaders and team members because team members are likely to attend to leaders' mood cues due to the latter's elevated position in the power hierarchy. In line with this, Sy et al. (2005) found that leaders' emotions impact the affective tone of their followers. While the PsyCap components of self-efficacy and resilience are primarily cognitive resources, hope and optimism have affective qualities that make them susceptible to contagion (Bono \& Ilies, 2006; Norman, Luthans, \& Luthans, 2005). Contagion between leader's and team members' hope and optimism may in turn influence teams' higher order PsyCap because the components of PsyCap have synergies and causal pathways between them. That is, if a team member has increased optimism and hope, it will likely lead to increased resilience and self-efficacy, and in turn, a global increase in PsyCap (Avey, Reichard, Luthans \& Mhatre, 2011). As the contagion effect from leader to team members is likely to affect team members similarly, team members may develop and express similar levels of hope and optimism, and thus the other two elements of PsyCap. This is likely to then lead to agreement among team members on the team's level of PsyCap, highlighting that team-level PsyCap is related to the leader's PsyCap.

Hypothesis 1. LPsyCap will be positively related to TPsyCap. 


\section{The Relationship between Team Psychological Capital and Team Outcomes}

The success of workplace teams has been shown to lead to many desired organizational outcomes such as productivity, profits, sales, customer retention, employee recruitment and retention (Denison, 1990; Harter, Schmidt \& Hayes, 2002; Ostroff, 1992). Thus, research examining the factors that foster positive team outcomes is important.

TPsyCap has been shown to be a factor that fosters positive teams. Here again though, the research is new and only three studies have been conducted, albeit showing positive findings. Heled et al. (2016) found a relationship between TPsyCap and OCB in school teams. In the banking industry, Walumbwa et al. (2011) showed that TPsyCap was positively related to team performance. Within the retail industry, Clapp-Smith et al. (2009) found that TPsyCap was related to financial performance of teams. Given the need for replicability in organization science (Tsang \& Kwan, 1999), more research is needed to confirm the TPsyCap-OCB and TPsyCap-team performance link. The current study investigates these relationships of TPsyCap with OCB and performance, and also adds a third team outcome, that of innovation (see Figure 1).

Figure 1

Proposed theoretical model of the mediated effects of principal PsyCap on SLTs' performance, innovation, and OCB.

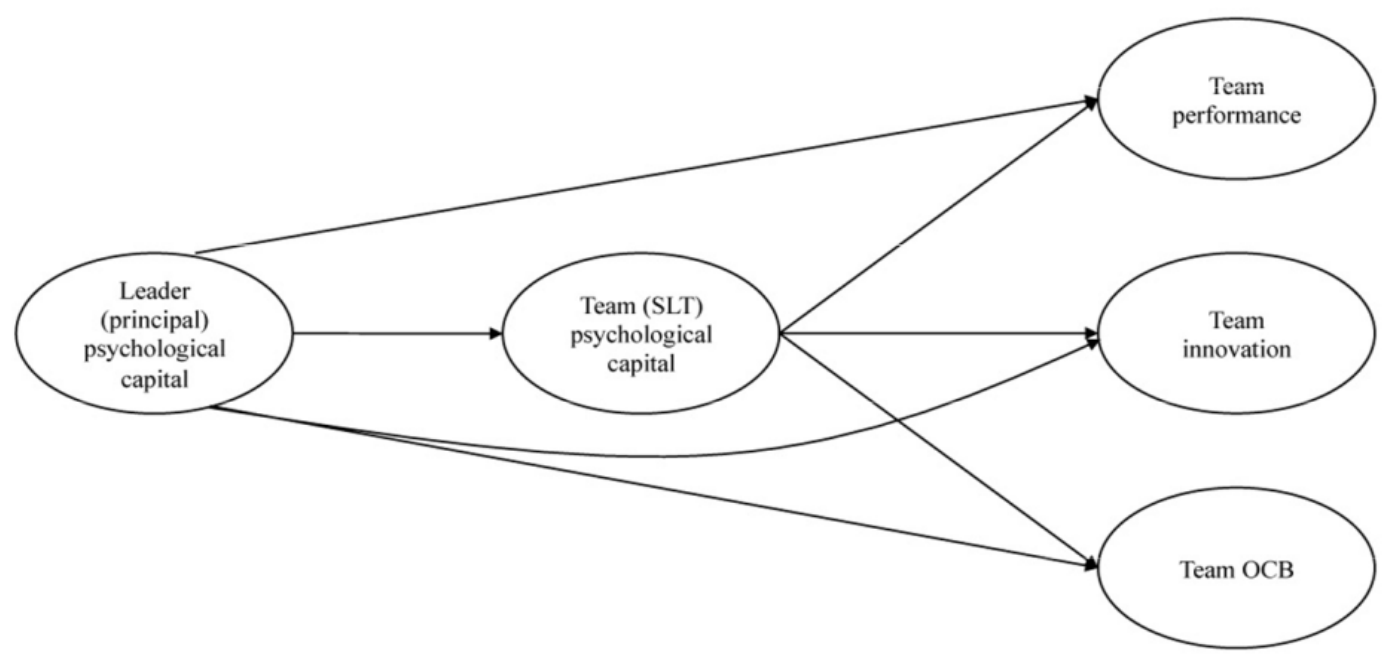

OCB. Organisational Citizenship Behavior represents "behavior that is discretionary, not directly or explicitly recognized by the formal reward system and that in the aggregate promotes the effective functioning of the organization" (Organ, 1988, p. 4). As with TPsyCap, team-level OCB refers to characteristic levels of OCB within groups (Vigoda-Gadot, Beeri, Birman-Shemesh, \& Somech, 2007). Support for the relationship between PsyCap and OCB is drawn from the wellestablished social-psychological finding that people with high levels of positive affect are more 
likely to help others than are those in negative or neutral moods (Isen \& Baron, 1991). People in positive moods are more likely to engage in OCBs such as helping coworkers, engaging in organization-sponsored volunteer work, or supporting newcomers to the group. In addition to helping behaviors, George and Brief (1992) suggested that positive affect can also lead to other extrarole behaviors, such as protecting organizations, making constructive suggestions, and spreading goodwill. Researchers have found a similar relationship between group affective tone and group OCB (Chen, Lam, Naumann, \& Schaubroeck, 2005; George, 1990). As such, the positive relationship between affect and OCB has been found to operate at both the individual and group levels.

Team performance. There are two mechanisms through which TPsyCap may influence team performance: agentic capacity and team processes. At the core of TPsyCap is an agentic capacity representing the group's belief of success based on efficacy (Luthans et al., 2006). Luthans et al. (2011) explained that this agentic capacity can be manifested in terms of a broader range of hope pathways to achieve goals (e.g., Snyder, 2000). Agentic capacity can also enable the perseverance and ability of teams to resiliently bounce back from setbacks (e.g., Masten \& Reed, 2002), because agency influences the degree to which people and groups feel their actions will create change (Brown \& Westaway, 2011; List \& Pettit, 2011). Optimistic outlooks can broaden problem-solving (e.g., Seligman, 1990), and efficacy can heighten desire for success and confidence that the group has what it takes to achieve its goals (e.g., Bandura, 1997). In sum, TPsyCap is expected to improve team performance by facilitating stronger motivational forces to successfully accomplish goals and tasks.

TPsyCap may also impact team performance by improving team processes. Initial evidence suggests that it is positively associated with team coordination, cooperation, and cohesion and may be negatively associated with conflict. West, Patera, and Carsten (2009) investigated how team optimism, efficacy, and resilience (but not hope), as individual constructs, each related to team coordination, cooperation, cohesion, and conflict. The results were mixed: optimism, resilience, and efficacy each related to cooperation but not to conflict, and only team optimism related to coordination and cohesion. However, a combined measure of team optimism, efficacy, and resilience was positively related to coordination, cooperation, and cohesion, and negatively related to conflict, implying that PsyCap may be related to several team processes, most especially the communication, co-ordinational and relational process.

As identified in the team literature, these processes are related to team performance (West, Patera \& Carston, 2009). For example, meta-analysis findings reveal a negative relationship between team conflict (task and relational) and team performance, showing an effect size of -.23. Various reasons exist for this, including the fact that conflict creates disharmony amongst team member, depletes/spends important resources such as time and emotions, makes team members feel unsafe, and encourages individuals to place their own goals above those of the larger team (De Dreu \& Weingart, 2003). In relation to the team process of cohesion, Tekleab, Quigley and Tesluk's (2009) longitudinal research found that team cohesion was positively related to team performance, team satisfaction, and team viability. This may be because cohesion is a force that keep group members together (Andrews, Kacmar, Blakely, \& Bucklew, 2008), and helps them remain united in the pursuit of their objectives (Tekleab et al., 2009). When it comes to the team process of cooperation, research shows that teams high on cooperation emphasize equality, group accomplishments (as opposed to individual accomplishments), teamwork, information sharing, and helping behavior, all of which 
foster team performance. Finally, the team process of coordination is a significant predictor of work team performance, because it allows the team to create and share knowledge in a consistent and timely manner (Bowers, Salas, Prince \& Brannick, 1992).

Team innovation. The third team outcome variable we link to TPsyCap is team innovation. Innovation represents the generation and implementation of new ideas (Amabile, 1996). Within organizations, new ideas are generally proposed and implemented by teams, so identifying teamlevel predictors of innovation is important (Hülsheger, Anderson, \& Salgado, 2009). Researchers have shown that individual PsyCap is positively related to reported individual innovation (Luthans et al., 2011), creativity (Sweetman, Luthans, Avey, \& Luthans, 2011), and originality (Avey et al., 2012), but researchers have not yet examined these relationships at the team level.

Hypothesis 2. TPsyCap will be positively related to team OCB, performance, and innovation.

\section{Relationships between LPsyCap, TPsyCap and Team Outcomes}

The final component of our model pertains to the mechanism through which LPsyCap influences team outcomes. Thus far, it has been hypothesized that LPsyCap is positively related to TPsyCap (through social learning and emotional contagion), which will, in turn, positively influence team outcomes (through positive affect, prosocial relationships, agentic capacity, and team processes). It follows that LPsyCap should have an indirect positive effect on team performance, innovation, and OCB.

At the individual level, studies have supported a LPsyCap-followerPsyCap link for outcomes such as engagement (a related construct to OCB) (Xu, Liu \& Chung, 2017), performance (Walumbwa et al., 2010), and creativity (a related construct to innovation) (Avey et al., 2012). At the group level, there are no studies examining the mediating role of TPsyCap in the relationship between LPsyCap and team outcomes. Instead we must turn to related leadership constructs to hypothesize the 'LPsycCap - TPysCap - team outcomes' link. For example, authentic leadership has been shown to impact team OCB and performance (Walumbwa et.al., 2011), as well as cynicism and tolerance to workplace incivility (Megeirhi, Kilic, Avci, Afsar \& Abubakar, 2018), through TPsyCap. These findings may indicate that TPsyCap might also mediate the relationship between LPsyCap and team outcomes, given that leaders' levels of PsyCap have been found to be antecedent to their authentic leadership behaviors (Jensen \& Luthans, 2006). Leader humility has also been shown to facilitate the development of collective TPsyCap, which leads to higher team task allocation effectiveness and, thus, stronger performance (Rego et al., 2017)

Hypothesis 3. LPsyCap will be positively related to team OCB, performance, and innovation.

Hypothesis 4. TPsyCap will mediate the relationship between LPsyCap and team OCB, performance, and innovation.

\section{METHOD}

\section{Sample}

Principals and their senior leadership teams (SLTs) - including Human Resource Managers, Finance Managers, Information Technology Managers, Assistant Principals and Curriculum leaders - were recruited through the private and public school systems in Australia. Recruitment occurred through email using lists provided by school governing bodies, and through advertising via professional 
education associations. To be included, SLTs needed to consist of two or more members (excluding the Principal), and have $60 \%$ or more of the team participating in the research (within-team participation rates averaged between $55 \%$ and $57 \%$ in the organizational literature; Nesterkin \& Ganster, 2015). After excluding teams with inadequate participation rates, the sample size was 94 teams, comprising 456 team members reporting to 94 Principals (total $N=550$ ). Table 1 summarizes the sample's characteristics.

Table $1^{1}$

Sample Characteristics

Average $\quad$ Range SD

\begin{tabular}{lccc}
\hline SLT Members & 46 & $24-64$ & 10.01 \\
Age (Years) & 3 & $0-19$ & 2.83 \\
Tenure (Years) & 71 & $2-14$ & 2.18 \\
$\begin{array}{l}\text { Proportion Female (\%) } \\
\text { Team Members per SLT }\end{array}$ & 4.9 & $60-100$ & 0.15 \\
Within-Team Participation Rate (\%) & 85 & & \\
& & $33-64$ & 6.65 \\
Principals & 52 & $0-19$ & 4.03 \\
Age (Years) & 5 & & \\
Tenure (Years) & 52 & & \\
Proportion Female (\%) & & & \\
Frequency of Principal-Team Meetings & & \\
(\% of Teams) & 10 & & \\
Daily & 5 & & \\
Biweekly & 52 & & \\
Weekly & 27 & & \\
Fortnightly & 6 & & \\
Monthly &
\end{tabular}

The study of PsyCap in schools is of critical importance given the twenty-first century school reform agenda and the centrality of school leadership to school performance and improvement (Datnow \& Castellano, 2001; Leithwood \& Sun, 2012). The school reform agenda has also created a marked shift towards team-based work structures in schools that now have more decision-making authority than ever before (Cranston \& Ehrich, 2009). The team-based organizational re-structuring of schools dramatically heightens the importance of understanding the potential effects of a Principals' PsyCap on leadership teams' PsyCap and related outcomes. Recognizing the newly emerging importance and prevalence of SLTs in schools, several researchers have highlighted the importance of investigating factors that influence SLT functioning (Cranston \& Ehrich, 2005; Wallace, 2001). As

1 Sample characteristics are based on 94 teams comprised of 456 team members reporting to 94 principals. 
such, the current study investigates the role of leader (Principal) and team PsyCap in SLT functioning.

\section{Procedure}

Participants were contacted via an email that explained the purpose of the study and contained a link to a secure online survey. Principals completed survey measures soliciting self-ratings of PsyCap and ratings of performance, innovation, and OCB of SLTs. At the end of the survey, Principals nominated the members of their SLTs to participate in the study by providing names and email addresses. An automatic email was then generated on behalf of the researchers and sent to SLT members inviting them to complete measures of TPsyCap. In total, 166 Principals participated (participation \% rate is unknown because the study was advertised). Principals nominated a total of 796 team members, 556 of whom participated (70\% participation rate).

This study was approved by the University of Melbourne's Human Research Ethics Committee. Participants were informed of the details of the study using a Plain Language Statement and gave their written consent to participate. Participants were free to withdraw at any time. Once the data was matched (Principal to school team), the data were de-identified for the purposes of analyses. Data were stored electronically in a secure site. Upon completion of the study, a final report was lodged with the University of Melbourne's Human Research Ethics Committee to confirm that all ethical procedures were adhered to. All procedures in this study were enacted according to the Ethics Approval granted by the University and complied with the National Statement on Ethical Conduct in Human Research.

\section{Measures}

\section{Measures completed by Principals.}

Leader PsyCap was measured with the 12-item Psychological Capital Questionnaire (PCQ-12; Luthans, Avolio \& Avey, 2007). The items were descriptive, first-person statements and asked Principals to rate their own PsyCap. Sample items include "I can think of many ways to reach my current work goals" (hope) and "I can get through difficult times at work because I've experienced difficulty before" (resilience). Response anchors for this scale and all others were 1 (Strongly disagree) and 6 (Strongly agree). Maximum score was 72. Cronbach's alpha was .81, showing strong reliability for this survey in the current sample.

Team performance was measured using a modified version of the 7-item scale by Williams and Anderson (1991). Principals were asked to rate the degree to which members of their leadership team met the formal requirements of their jobs. The following is an example item from this scale: "Members of this team adequately complete their assigned duties" $(\alpha=.88)$.

Team $O C B$ was measured using a modified version of the 14-item scale by Williams and Anderson (1991). The scale was modified by shifting the referent from individual employees to the team as a whole. Principals rated the degree to which members of their leadership team engaged in OCB. The following is an example item from this scale: "Members of the leadership team help others who have heavy workloads" ( $\alpha=.87$ ).

Team innovation was measured using a 4-item, team-level scale developed by Drach-Zahavy and Somech (2001). This scale is a version of the innovation scale by West and Wallace (1991) that 
has been modified for use with teachers. The scale asked Principals to rate the degree to which members of their leadership team had initiated changes in each of four job areas: work objectives, 2) working methods, 3) teaching methods, and 4) development of skills. The following is an example item from this scale: "Members of the leadership team initiate new procedures and methods" $(\alpha=$ $.90)$.

\section{Measures completed by SLT members.}

Team psychological capital was measured using the revised psychological capital questionnaire, which is designed to evaluate the team's collective PsyCap (Mathe-Soulek et al., 2014). Each participant rated their team's PsyCap based on two items for each of the HERO dimensions. This referent shift approach (Chan, 1998) was also used by West et al. (2009) in their assessment of team efficacy, resilience, and optimism. The following is a sample item from this scale: "Members of the leadership team think of many ways to reach work goals" (hope) (individual-level $\alpha=.86$, team-level $\alpha=.92$ ).

\section{Levels of Measurement}

Klein and colleagues (Klein, Dansereau \& Hall, 1994; Klein \& Kozlowski, 2000) have emphasized the importance of measuring a construct at the same level that it is conceptualized. In this study, there was one measure per team of LPsyCap, TPsyCap, team performance, team innovation, and team OCB.

TPsyCap was conceptualized at the team level but measured at the individual level (i.e., each team member rated the team's PsyCap), and, thus, aggregation was required. To assess the appropriateness of aggregating individual scores to the team-level, three measures are generally used: ICC(1), ICC(2) and rwg (LeBreton \& Senter, 2008). In this study, ICC(1) was .22, $F(93,362)=2.36$, $p<.001$, and average rwg was .91, justifying aggregation to the team level. ICC(2) was .58, below the recommended value of .70 (Klein \& Kozlowski, 2000). As low ICC(2) values are likely to attenuate relationships observed at the group level (Bliese, 1998), results presented using the aggregated measure of TPsyCap should be interpreted as conservative. Given the acceptable levels of ICC(1) and $\mathrm{rwG}$, and noting the potential for attenuation due to low ICC(2), individual measures of TPsyCap were aggregated to the team level.

\section{Analytic Procedures}

Structural equation modelling (SEM) using Mplus 6.12 was used to test hypotheses. SEM was chosen because it allows for simultaneous estimation of all regression coefficients, which provides the best balance between power and type I error rates, particularly for mediation analyses (MacKinnon, Lockwood, Hoffman, West, \& Sheets, 2002). The 2-step approach by Anderson and Gerbing (1988) was applied by first examining the measurement model and subsequently assessing alternative structural models for evaluating hypothesized relationships.

Use of SEM in this study necessitated the use of multi-item parcels to retain an acceptable sample-size-to-indicator ratio (Bentler \& Chou, 1987). Principal PsyCap and SLT PsyCap were each divided into four parcels, aligned to the resources of hope, efficacy, resilience and optimism. Performance was divided into three parcels (two parcels of two items and one parcel of three items), and OCB was divided into four parcels (two parcels of three items and two parcels of four items). 


\section{RESULTS}

\section{Descriptive Statistics and Preliminary Data Analysis}

Table 2 provides the descriptive statistics for all scales. Correlational analysis found that leader's PsyCap was significantly related to team innovation and organizational citizenship behavior but unrelated to team performance and team PsyCap. The shared PsyCap of the team was significantly correlated with all three team outcomes.

Table $2^{2}$

Descriptive Statistics and Spearman Rank-Order Correlations of Scales

\begin{tabular}{lllllllll}
\hline Scale & & Mean & SD & 1 & 2 & 3 & 4 & 5 \\
\hline 1. & Leader PsyCap & 5.24 & .47 & $(.81)$ & & & & \\
2. & Team PsyCap & 4.97 & .43 & -.05 & $(.92)$ & & & \\
3. & Team performance & 5.34 & .63 & .15 & $.41^{* * *}$ & $(.88)$ & & \\
4. & Team innovation & 5.16 & .71 & $.39^{* * *}$ & $.36^{* * *}$ & $.56^{* * *}$ & $(.90)$ & \\
5. & Team OCB & 5.37 & .51 & $027^{* *}$ & $.46^{* * *}$ & $.65^{* * *}$ & $.69^{* * *}$ & $(.87)$ \\
\hline
\end{tabular}

\section{Model Specification}

Measurement model. The measurement model (CFA1) had generally acceptable fit to the data: $\chi 2(142)=204.02, p=<.001, \chi^{2} / \mathrm{df}=1.44, \mathrm{CFI}=.94, \mathrm{RMSEA}=.07, \mathrm{SRMR}=.06$. Though RMSEA, SRMR, and $\chi^{2} / \mathrm{df}$ were within the acceptable range, CFI was below the generally accepted cutoff of .95 (Kline, 2011). Modification indices were examined to determine potential improvements to the model. Results from the Mplus output suggested two theoretically plausible modifications: addition of covariances between two of the performance-indicator parcels, and addition of covariances between two of the innovation indicators. A Satorra-Bentler (Satorra \& Bentler, 2001) scaled chisquare difference test indicated that the modified model fit the data significantly better $\left(T_{d}[2]=17.45\right.$, $p<.001)$, and all fit indices met the required cutoff criteria: $\chi^{2}(140)=180.727, p<.05, \chi^{2} / \mathrm{df}=1.29$, CFI $=.96, \mathrm{RMSEA}=.06, \mathrm{SRMR}=.06$. The modified measurement model (CFA2) was therefore used to estimate the structural model.

Structural model. Following Anderson and Gerbing's (1988) recommendations, alternative structural models that were theoretically plausible were examined before testing hypotheses. The base model (M1) was the fully mediated model, in which TPsyCap fully accounts for the associations between LPsyCap and team outcomes. The base model was then re-specified as a partially mediated model (M2; see Figure 1) by adding pathways between LPsyCap and team performance, team innovation, and team OCB.

A Satorra-Bentler scaled chi-square difference test (Satorra \& Bentler, 2001) revealed that the fit of M2 was significantly better than was the fit of M1 $\left(\mathrm{T}_{\mathrm{d}}[3]=17.04, p<.001\right)$. The partially mediated model (M2) was therefore considered the superior model and was selected for hypothesis testing. The fit measures for all tested models are included in Table 3.

2 Correlations and internal reliabilities (Cronbach's $\alpha$ ) are based on $N=94$ teams. Scale reliabilities appear on the diagonal in parentheses. ${ }^{* *} \mathrm{p}<.01$ (two-tailed test), $* * * \mathrm{p}<.001$ (two-tailed test). 
Table $3^{3}$

Model Fit Indices of Measurement Models and Structural Models

\begin{tabular}{llllll}
\hline Model & df & $\chi^{2}$ & RMSEA & SRMR & CFI \\
\hline CFA1 & 142 & 204.02 & .07 & .06 & .94 \\
CFA2 & 140 & 180.73 & .06 & .06 & .96 \\
M1 & 143 & 201.22 & .07 & .11 & .95 \\
M2 & 140 & 180.73 & .06 & .06 & .96 \\
\hline
\end{tabular}

\section{Hypothesis Testing}

SEM results for M2 are displayed in Figure 2: $\chi^{2}(140)=180.727, p=<.05, \chi^{2} / d f=1.29, \mathrm{CFI}=.96$, RMSEA $=.06, \mathrm{SRMR}=.06$. Results indicated a nonsignificant relationship between LPsyCap and TPsyCap $(\beta$ $=-.04, n s)$. Thus, hypothesis one was not supported. The second hypothesis predicted that TPsyCap would be related to team OCB, team performance, and team innovation. As shown in Figure 2, TPsyCap was significantly related to all three measures of team outcomes: team OCB $(\beta=.50, p<$ $.001)$, team performance $(\beta=.50, p<.001)$, and team innovation $(\beta=.37, p<.001)$. Thus, hypothesis two was supported.

Figure 2

Estimated path coefficients for the chosen structural model (M2) ${ }^{4}$

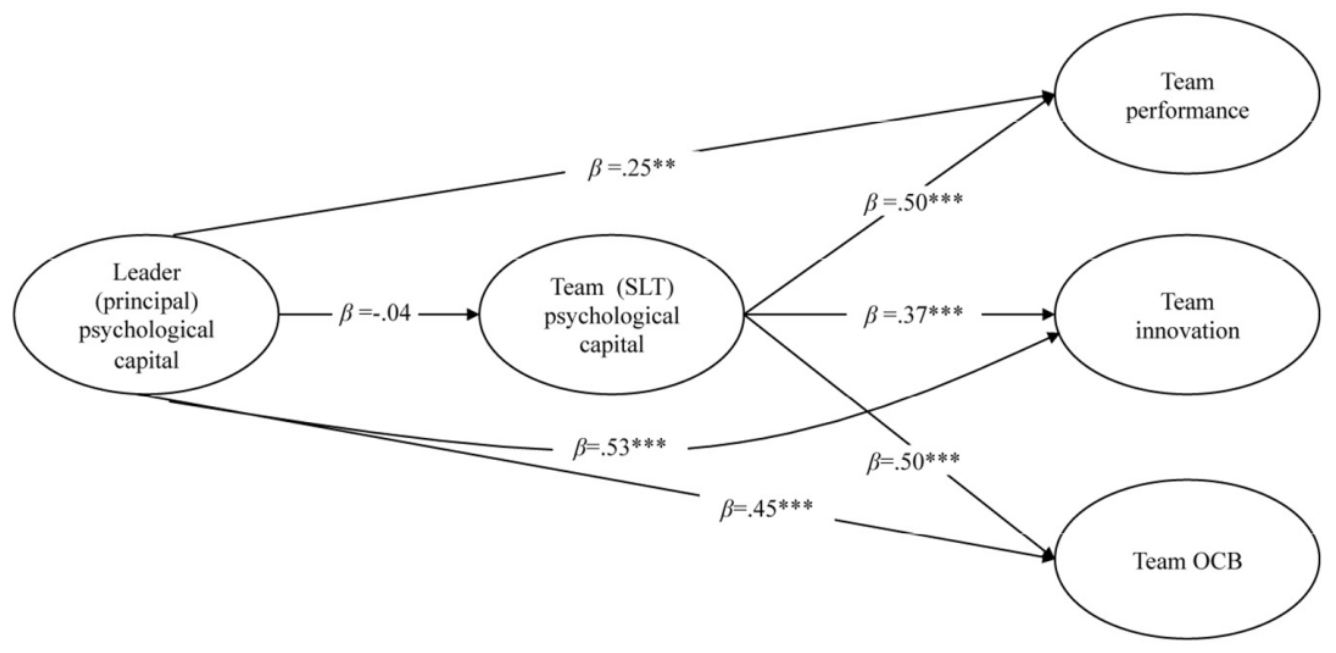

Hypothesis three - that LPsyCap would be positively related to team OCB, team performance, team innovation and team OCB - was supported (see Figure 2). LPsyCap was significantly related to team

${ }^{3}$ CFA1 and CFA2 are measurement models. M1 and M2 are structural models.

4 Parameters are standardized MLM estimates. ${ }^{* *} \mathrm{p}<.01$ (two-tailed), ${ }^{* * *} \mathrm{p}<.001$ (two-tailed) 
$\operatorname{OCB}(\beta=.45, p<.001)$, team performance $(\beta=.25, p<.01)$, team innovation $(\beta=.53, p<.001)$, and team $\operatorname{OCB}(\beta=.45, p<.001)$.

The fourth hypothesis stated that TPsyCap would mediate the relationship between LPsyCap and team outcomes. However, this hypothesis could not be tested as it did not meet the requirements of mediation, owing to the fact that the independent variable (LPsyCap) was not significantly related to the mediating variable (TPsyCap) (Preacher \& Hayes, 2004).

\section{Assessment of Potential Covariates}

As a final step in the analysis, the impact of the covariates of leader gender, meeting frequency (coded as $1=$ daily to $5=$ monthly), and average team tenure on path coefficients was examined. Fisher's Z-tests indicated that the size of the path coefficients did not significantly differ (all Zs, $n s$ ) when controlling for the potential covariates, indicating that the model was not affected by these covariates.

\section{DISCUSSION}

The field of POB aims to build theory and research on positive aspects of individual, team, and organizational performance (Turner, Barling, \& Zacharatos, 2002). PsyCap has been a topic of considerable interest within this field (Bakker \& Schaufeli, 2008; Luthans, Avolio, Avey, \& Norman 2007), and while much has been published about the effects of PsyCap on individual employee performance and wellbeing (Donaldson \& Ko, 2010), comparatively little is known about team-level PsyCap. The current study, thus, makes an important contribution to the field of POB by focusing on PsyCap as a team construct, and by using a mediated model to consider factors that might promote TPsyCap (particularly LPsyCap), as well as examining a range of team-level outcomes that might arise from TPsyCap (i.e., performance, innovation, and OCB).

\section{The Relationship between LPsyCap and TPsyCap}

In relation to our examination of factors that might promote TPsyCap, we hypothesized that LPsyCap would be a significant contributor. We based this hypothesis on past research showing a significant leader-to-follower PsyCap relationship (Klein et al., 1994), and by using the theoretical explanations of modelling and contagion effects to lift this up to the team-level. However, in the current study, the leader-follower PsyCap relationship was not significant at the team level. This result is inconsistent with other studies showing that leadership more strongly affects team-level outcomes than individual-level outcomes. For example, researchers have shown that leadership more strongly affects collective efficacy than individual efficacy, and team performance more than individual performance (Chen \& Bliese, 2002; DeGroot, Kiker, \& Cross, 2000).

It is worth noting that the nonsignificant relationship between LPsyCap and TPsyCap remained when controlling for leader gender, team tenure, and meeting frequency. Moreover, although the low ICC (2) of team-level PsyCap had the potential to attenuate relationships, the negligible path coefficient $(\beta=-.01)$ suggested that non-significance was not due to attenuation.

Given the lack of prior research of TPsyCap, we do not have strong evidence at the team level to support or contradict the current finding. However, it is worth considering if the results of this study may be methodologically driven due to the fact that we asked leaders to self-rate their 
levels of PsyCap. We followed the precedent of prior studies of PsyCap who use leader self-ratings (e.g., Walumbwa et al., 2010), but it is possible that the self-rated PsyCap of the Principals did not accurately reflect the way their SLTs perceived that Principal's PsyCap. According to Bandura (1986), it is the observers' perceptions of stimuli that determine what will be modelled, as opposed to the model's perceptions of him/herself. If the school Principal's self-rating were discordant with the way the team saw them, this may have weakened the statistical relationship between LPsyCap and TPsyCap. This idea warrants further attention, and future researchers may choose to have team members rate their leader's PsyCap together with the leader conducting a self-rating.

\section{The Relationship between TPsyCap, LPsyCap, and Team Outcomes}

Turning our attention to the team-level outcomes of TPsyCap, a significant relationship was found between TPsyCap and performance, OCB, and innovation, suggesting that building up the shared efficacy, optimism, hope, and resilience of work teams is an effective goal for organizations to pursue. The results of this study replicated the relationship between TPsyCap with team performance and OCB found in samples of retailers (Clapp-Smith et al., 2009) and bankers (Walumbwa et al., 2011), and in one other educational sample (Heled et al., 2016). In the current schools, SLTs who had high levels of shared PsyCap had higher team outcomes. Prior research has shown that the components of hope, efficacy, resilience, and optimism in a team lead to increased motivation to put effort into successfully accomplishing goals and tasks (Avey, Reichard et al., 2011) and this could be the underlying mechanism explaining the current finding. PsyCap may also increase team outcomes by impacting team processes, such as coordination, cooperation, cohesion, and conflict (West et al., 2009). Now that the relationship has been identified between TPsyCap and team outcomes, future researchers could turn their attention to exploring the underlying mechanisms.

In addition to team outcomes being predicted by TPsyCap, the current study also found that team outcomes were directly positively associated with LPsyCap. In thinking about what sits underneath this relationship, we speculate that leaders with high hope and resilience may assist their teams to navigate roadblocks and bounce back from setbacks, thus contributing to team outcomes. Moreover, the increased confidence of optimistic and self-efficacious leaders in their teams' abilities to implement innovative change and achieve performance targets may influence their teams to act accordingly. Finally, given the positive relationship between individual PsyCap and OCB (Avey, Reichard et al., 2011), and the finding that followers tend to enact behaviors that their leaders emphasize (Schneider, Ehrhart, Mayer, Saltz \& Niles-Jolly, 2005), leaders with higher PsyCap may engage in and model increased OCB. As such, leaders with high PsyCap may facilitate improved team performance, innovation, and OCB independently of an effect on TPsyCap.

Contrary to our prediction in hypothesis four, TPsyCap did not mediate the relationship between LPsyCap and team outcomes. This is because, as outlined above, there was no direct relationship between LPsyCap and TPsyCap. The current finding suggests that organisations seeking to build TPsyCap need to be cautious in over-relying on the leader to cultivate TPsyCap, and instead might be wiser to explore other channels of cultivating TPsyCap, such as TPsyCap training and interventions (Luthans, Avey, Avolio, Norman, \& Combs, 2006; Luthans et al., 2008; Williams et al., 2016). 
Practical Implications, Study Limitations and Future Research

To date, workplace PsyCap interventions have been tailored at the individual level (see Luthans, Avey, \& Patera, 2008; Williams et al., 2016), but the current findings open up an interesting pathway for the design of team-level interventions that foster a shared perception of TPsyCap. These interventions would be designed to encourage common mental models across group members about the team's level of hope, efficacy, resilience, and optimism. Two such interventions might include a reflected 'best team' appreciative inquiry exercise, and a 'HERO heroes' exercise.

The design of a reflected 'best team' intervention could adapt the reflected best self-exercise (Morgan Roberts, Dutton, Spreitzer, Heaphy, \& Quinn, 2005) to the team level, and use the Appreciative Inquiry (AI) principles of collaboration and inquiry (Cooperrider, 2012) to invite team members to reflect on a time when the team was at its best. Following the AI method, these reflections would be used to determine the positive core of the team, which could be analyzed for evidence of hope, efficacy, resilience, and optimism. Research has shown that reflection on past team performance shapes a sense of collective self-efficacy (Riggs \& Knight, 1994; Watson et al., 2001). Moreover, Ludema, Wilmot, and Srivasta (1997) recommend that when organizations create opportunities for reflection and dialogue to affirm the best (and most promising) aspects of the workplace, this creates "organizational hope" (p. 1015). Their suggestion for "textured vocabularies of hope" (p.1016) can be explicitly woven into the reflected 'best team' intervention which is designed to bolster shared mental models of TPsyCap.

The design of a 'HERO heroes' exercise would ask team members to identify and observe other work teams they have identified as being high on HERO (hope, efficacy, resilience and optimism) - in other words, their TpsyCap heroes. This idea for an intervention is based on the research into vicarious experiences, and what happens when we observe and copy people whose thoughts, emotions, and actions are those we seek to develop. Bandura (1986) theorized that vicarious experience is a powerful influence on efficacy development. At the group level, Winett, Leckliter, and Chinn (1985) found a significant relationship between group modeling and group effectiveness. Similarly, the 'vicarious experience' group of participants in Prussia and Kinicki's (1996) study who watched a video of a high-quality team engaging in brainstorming, reported a significant positive link between this vicarious experience and their sense of collective self-efficacy with their teams. In nursing, McAllistar and McKinnon (2009) suggest that nurses develop resilience through observing their colleagues and, as such, hospitals and teaching universities need to create opportunities for resilience development through internships, work integrated learning, and other work experiences. The evidence outlined above can be used to suggest that an intervention which encourages teams to identify and observe other teams who are high on HERO may be an effective way to boost their own TPsyCap.

When considering the design of the interventions above, platforming off the current results, the limitations of this study must be recognized. For example, the lack of relationship between LPsyCap and TPsyCap may be specific to schools, and this raises one of the limitations of the current study. It may be that leaders in other industries or work settings have a stronger impact on TPsyCap if the teams operate more closely in the way tasks are completed and/or the physical proximity in which they work. School leadership teams are typically situated in separate offices (sometimes in different areas of the school), and don't have the same degree of daily task interdependence as other 
industries such as manufacturing or retail. As such, the conclusions drawn above could be considered as sector-specific, and we must be careful not to over-generalize. Additionally, the fact that this study was conducted in Australia may make the results ungeneralizable to school systems in other countries and, especially, school leadership teams in non-Western societies.

The caution not to over-generalize also applies to several methodological limitations that must be kept in mind when considering the findings of the current study. The study is correlational, and as such, causal inferences cannot be drawn from the results. Further, there is a risk of commonsource bias for LPsyCap and ratings of team outcomes (Podsakoff, MacKenzie, \& Podsakoff, 2012) as they were both rated by the school Principals. It is possible that those Principals with high PsyCap themselves may have provided upwardly-biased ratings of the teams, on account of their own high levels of optimism and efficacy. Indeed, it has been proposed that both optimism and positive affect are associated with attentional bias for positively valenced stimuli (Bower, 1994; Segerstrom, 2001).

Future researchers are encouraged to re-test these relationships using different sources of LPsyCap and team outcomes in order to reduce the effects of common source bias (Podsakoff, MacKenzie, Lee, \& Podsakoff, 2003). Future researchers might also consider potential moderating factors of the relationship between LPsyCap and TPsyCap, such as the leader's personality and years in leadership, the levels of agency and autonomy granted to the school leader and leadership team by the District Board, as well as the school's type (public/private; primary/secondary) and socioeconomic status.

A strength of this study lies in the multi-source design used where teams rated their own TPsyCap independently of the ratings of team performance. Another strength lies in the large sample size compared to previous TPsyCap studies ( $N=94$ teams, $n=550$ team members), the use of psychometrically valid measures, and the extension from prior industries studied into the education sector. To date, the effects of leaders' PsyCap have been tested in samples such as engineers, policeman, and senior business people (Avey, Avolio \& Luthans, 2011; Avey et al., 2012; Walumbwa et al., 2010).

\section{Conclusion}

The current study was interested in exploring PsyCap at the team level and investigating whether TPsyCap predicts team outcomes. This referent shift provides an evolution of the PsyCap literature, which has predominantly focused on PsyCap within individuals. Situated within the POS and POB fields, the current study suggest that TPsyCap is an important team-level resource at work. More particularly, the study indicates that school leadership teams benefit when they build up shared HERO (hope, efficacy, resilience and optimism). We encourage ongoing research into the antecedents and outcomes of team-level PsyCap across multiple sectors.

\section{Authors}

Lea Waters

Centre for Positive Psychology

University of Melbourne

l.waters@unimelb.edu.au

Gabriel Strauss 
University of Melbourne

strauss@gmail.com

Anit Somech

Educational and Leadership Policy Unit

University of Haifa

anits@edu.haifa.ac.il

Nick Haslam

School of Psychological Sciences

University of Melbourne

hhaslam@unimelb.edu.au

Denise Dussert

University of Melbourne

d.dussert77@gmail.com

\section{Publishing Timeline}

Received 30 May 2019

Accepted 30 November 2019

Published 1 February 2020

\section{References}

Abbas, M., Raja, U., Darr, W., \& Bouckenooghe, D. (2014). Combined effects of perceived politics and psychological capital on job satisfaction, turnover intentions, and performance. Journal of Management, 40(7), 1813-1830. doi: 10.1177/0149206312455243

Al Rahbi, D., Khalid, K., \& Khan, M (2017). The effects of leadership styles on team motivation. Academy of Strategic Management Journal, 16(2), 1-14. doi: 1939-6104-16-2-113

Amabile, T. M. (1996). Creativity in context: Update to the social psychology of creativity. Boulder, CO: Westview Press.

Anderson, J. C., \& Gerbing, D. W. (1988). Structural equation modelling in practice: A review and recommended two-step approach. Psychological Bulletin, 103, 411-423. doi:10.1037/0033-2909.103.3.411

Andrews, M. C., Kacmar, K. M., Blakely, G. L., \& Bucklew, N. S. (2008). Group cohesion as an enhancement to the justice affective commitment relationship. Group \& Organization Management, 33, 736-755.

Anglin, A., McKenny, A., \& Short, J. (2018). The impact of collective optimism on new venture creation and growth: A social contagion perspective. Entrepreneurship Theory and Practice, 42, 390-425.

Avey, J. B., Luthans, F., \& Jensen, S. M. (2009). Psychological capital: A positive resource for combating employee stress and turnover. Human Resource Management, 48, 677-693. doi: 10.1002/hrm.20294

Avey, J. B., Luthans, F., \& Youssef, C. M. (2010). The additive value of positive psychological capital in predicting work attitudes and behaviors. Journal of Management, 36, 430-452. doi: 10.1177/0149206308329961

Avey, J. B., Avolio, B. J., \& Luthans, F. (2011). Experimentally analyzing the impact of leader positivity on follower positivity and performance. The Leadership Quarterly, 22, 282-294. doi:

10.1016/j.leaqua.2011.02.004

Avey, J. B., Reichard, R. J., Luthans, F., \& Mhatre, K. H. (2011). Meta-analysis of the impact of positive 
psychological capital on employee attitudes, behaviors, and performance. Human Resource Development Quarterly, 22(2), 127-152. doi: 10.1002/hrdq.20070

Avey, J. B., Richmond, F., \& Nixon, D. R. (2012). Leader positivity and follower creativity: An experimental analysis. The Journal of Creative Behavior, 46(2), 99-118. doi: 10.1002/jocb.8

Bakker, A., \& Schaufeli, W. (2008). Positive organizational behavior: Engaged employees in flourishing organizations. Journal of Organizational Behavior, 29, 147-154. doi: 10.1002/job.515

Bandura, A., Ross, D., \& Ross, S. A. (1961). Transmission of aggression through imitation of aggressive models. Journal of Abnormal and Social Psychology, 63(3), 575-582. doi: 10.1037/h0045925

Bandura, A. (1977a). Social learning theory. Englewood Cliffs, NJ: Prentice-Hall.

Bandura, A. (1977b). Self-efficacy: Toward a unifying theory of behavioral change. Psychological Review, 64, 191-215.

Bandura, A. (1986). Social foundations of thought and action: A social cognitive theory. Englewood Cliffs, NJ: Prentice-Hall.

Bandura, A. (1997). Self-efficacy: The exercise of control. New York, NY: Freeman.

Bar-Tal, D. (2001) Why does fear override hope in societies engulfed by intractable conflict, as it does in the Israeli society? Political Psychology, 22, 601-627.

Bennett, J. B., Aden, C. A., Broome, K., Mitchell, K., \& Rigdon, W. D. (2010). Team resilience for young restaurant workers: Research-to-practice adaptation and assessment. Journal of Occupational Health Psychology, 15, 223-236.

Bentler, P. M., \& Chou, C. P. (1987). Practical issues in structural modeling. Sociological Methods \& Research, 16(1), 78-117. doi: 10.1177/0049124187016001004

Bliese, P. D. (1998). Group size, ICC values, and group-level correlations: A simulation.

Organizational Research Methods, 1(4), 355-373. doi: 10.1177/109442819814001

Bono, J. E., \& Ilies, R. (2006). Charisma, positive emotions and mood contagion. The Leadership Quarterly, 17(4), 317-334. doi: 10.1016/j.leaqua.2006.04.008

Bower, G. H. (1994). Some relations between emotion and memory. In P. Ekman \& R. J. Davidson (Eds.), The nature of emotions (pp. 303-305). Oxford: Oxford University Press.

Bowers, C., Salas, E., Prince, C., \& Brannick, M. (1992). Games teams play: A method for investigating team coordination and performance. Behavior Research Methods, Instruments, \& Computers, 24, 503-506.

Braithwaite, V. (2004). Collective hope. The Annals of the American Academy of Political and Social Science, 592, 6-15.

Brown, K., \& Westaway, E. (2011). Agency, capacity, and resilience to environmental change. Annual Review of Environment and Resources, 36, 321-342.

Carmeli, A., Friedman, Y., \& Tishler, A. (2013). Cultivating a resilient top management team: The importance of relational connections and strategic decision comprehensiveness. Safety Science, 51, 148-159.

Chan, D. (1998). Functional relations among constructs in the same content domain at different levels of analysis: A typology of composition models. Journal of Applied Psychology, 83(2), 234-246. doi: 10.1037/0021-9010.83.2.234

Chen, G., \& Bliese, P. D. (2002). The role of different levels of leadership in predicting self- and collective efficacy: Evidence for discontinuity. Journal of Applied Psychology, 87(3), 549-556. doi: 10.1037/00332909.107.1.48

Chen, X.-P., Lam, S. S. K., Naumann, S. E., \& Schaubroeck, J. (2005). Group citizenship behaviour: Conceptualization and preliminary tests of its antecedents and consequences. Management and Organization Review, 1(2), 273-300. doi: 10.1111/j.1740-8784.2005.00012.x

Chen, S. (2015). The relationship of leader psychological capital and follower psychological capital, job engagement and job performance: A multilevel mediating perspective. The International Journal of Human Resource Management, 26(18), 2349-2365. doi: 10.1080/09585192.2015.1020443 
Chen Q., Wen Z., Kong Y., Niu, K., \& Hau, K. (2017). Influence of leaders' psychological

capital on their followers: Multilevel mediation effect of organizational identification. Frontiers in Psychology, 8, 1-12. doi: 10.33389fpsyg.2017.01776

Christakis, N. A., \& Fowler, H. J. (2008). Social networks and happiness. Retrieved from http://www.edge.org/3rd_culture/christakis_fowler08/christakis_fowler08_index.html

Clapp-Smith, R., Vogelgesang, G. R., \& Avey, J. B. (2009). Authentic leadership and positive psychological capital. Journal of Leadership \& Organizational Studies, 15(3), 227-240. doi: 10.1177/1548051808326596

Cooperrider, D. (2012). The concentration effect of strengths: How the whole system "AI" summit brings out the best in human enterprise. Organisational Dynamics, 41, 106-117.

Cranston, N., \& Ehrich, L. (2005). Enhancing the effectiveness of senior management teams in schools. International Studies in Educational Administration, 33(1), 79-91. doi:10.1111/j.1529-1006.2006.00030.x

Cranston, N., \& Ehrich, L. (2009). Senior management teams in schools: Understanding

their dynamics, enhancing their effectiveness. Leading and Managing, 15(1), 14-25.

Datnow, A., \& Castellano, M. E. (2001). Managing and guiding school reform: Leadership in success for all schools. Educational Administration Quarterly, 37(2), 219-249. doi: 10.1177/00131610121969307

Dawkins, S., Martin, A., Scott, J., \& Sanderson, K (2015). Advancing conceptualization and measurement of psychological capital as a collective construct. Human Relations, 68(6), 925-949. doi: $10.1177 / 0018726714549645$

De Dreu, C. K. W., \& Weingart, L. R. (2003). Task versus relationship conflict, team performance, and team member satisfaction: A meta-analysis. Journal of Applied Psychology, 88, 741-749. doi:10.1037/ 00219010.88.4.741

DeChurch, L., Hiller, N., Murase, T., Doty, D., \& Salas, E. (2010). Leadership across levels: Levels of leaders and their levels of impact. The Leadership Quarterly, 21, 1069-1085. doi: doi:10.1016/j.leaqua.2010.10.009

DeGroot, T., Kiker, D. S., \& Cross, T. C. (2000). A meta-analysis to review organizational outcomes related to charismatic leadership. Canadian Journal of Administrative Sciences, 17(4), 356-371. doi: 10.1111/j.19364490.2000.tb00234.x

Denison, D. R. (1990). Corporate culture and organizational effectiveness. New York: John Wiley.

Devine, D. J., Clayton, L. D., Philips, J. L., Dunford, B. B., \& Melner, S. B. (1999). Teams in Organizations. Small Group Research, 30(6), 678-711.

Donaldson, S. I., \& Ko, I. (2010). Positive organizational psychology, behavior, and scholarship: A review of the emerging literature and evidence base. The Journal of Positive Psychology, 5(3), 177-191. doi: 10.1080/17439761003790930

Drach-Zahavy, A., \& Somech, A. (2001). Understanding team innovation: The role of team processes and structures. Group Dynamics, 5(2), 111-123.

Eden, D. (1992). Leadership and expectations: Pygmalion effects and other self-fulfilling prophecies in organizations. The Leadership Quarterly, 3(4), 271-305. doi:

10.1016/1048-9843(92)90018-b

Fredrickson, B. L. (1998). What good are positive emotions? Review of General Psychology, 2(3), 300-319. doi: 10.1037/1089-2680.2.3.300

George, J. M. (1990). Personality, affect, and behavior in groups. Journal of Applied Psychology, 75(2),107-116. doi: 10.1037/0021-9010.75.2.107

George, J. M., \& Brief, A. P. (1992). Feeling good-doing good: a conceptual analysis of the mood at workorganizational spontaneity relationship. Psychological Bulletin, 112(2), 310-329. doi: 10.1037/00332909.112.2.310

Hackman, J. R., \& Walton, R. E. (1986). Leading groups in organizations. In P. S. Goodman (Ed.), Designing effective work groups. San Francisco, CA: Jossey-Bass.

Hatfield, E., Cacioppo, J. T., \& Rapson, R. L. (1994). Emotional contagion. New York: Cambridge University 
Press.

Harter, J.K., Schmidt, F.L., \& Hayes, T. (2002). Business-unit-level relationship between employee satisfaction. Journal of Applied Psychology, 87(2), 268-279

Heled, E., Somech, A., \& Waters, L. (2016). Psychological capital as a team phenomenon:

Mediating the relationship between learning climate and outcomes at the individual and team levels. The Journal of Positive Psychology, 11(3), 303-314. doi: 10.1080/17439760.2015.1058971

Hmieleski, K. M., Cole, M. S., \& Baron, R. A. (2012). Shared authentic leadership and new venture performance. Journal of Management, 38(5), 1476-1499. doi:

10.1177/0149206311415419

Hobfoll, S. E. (2002). Social and psychological resources and adaptation. Review of General Psychology, 6(4), 307-324

Hodges, L., \& Carron, A. V. (1992). Collective efficacy and group performance. International Journal of Sport Psychology, 23, 48-59.

Hsu, S., Wang, Y., Chen Y., \& Dahlgaard-Park, S. (2014) Building business excellence through psychological capital, Total Quality Management $\mathcal{E}$ Business Excellence, 25(11), 1210-1223, doi: 10.1080/14783363.2014.913349

Hülsheger, U. R., Anderson, N., \& Salgado, J. F. (2009). Team-level predictors of innovation at work: a comprehensive meta-analysis spanning three decades of research. Journal of Applied Psychology, 94(5), 1128-1145. doi: 10.1037/a0015978

Isen, A. M., \& Baron, R. A. (1991). Positive affect as a factor in organizational behavior. In L. L. Cummings \& B. M. Staw (Eds.), Research in organizational behavior (pp. 1-53). Greenwich, CT: JAI Press.

Jensen, S. M., \& Luthans, F. (2006). Relationship between entrepreneurs' psychological capital and their authentic leadership. Journal of Managerial Issues, 18(2), 254-273.

Judge, T. A., Bono, J. E., Ilies, R., \& Gerhardt, M. W. (2002). Personality and leadership: A qualitative and quantitative review. Journal of Applied Psychology, 87(4), 765-780. doi: 10.1037//0021-9010.87.4.765

Klein, K. J., Dansereau, F., \& Hall, R. J. (1994). Levels issues in theory development, data collection, and analysis. The Academy of Management Review, 19(2), 195-229. doi:

$10.2307 / 258703$

Klein, K. J., \& Kozlowski, S. W. J. (2000). From micro to meso: Critical steps in conceptualizing and conducting multilevel research. Organizational Research Methods, 3(3), 211-236. doi:

10.1177/109442810033001

Kline, R. B. (2011). Principles and practice of structural equation modeling. New York,

NY: Guilford Press

Kozlowski, S. W. J., \& Chao, G. T. (2012). The dynamics of emergence: Cognition and cohesion in work teams. Managerial and Decision Economics, 33(5-6), 335-354. doi: 10.1002/mde.2552

LeBreton, J. M., \& Senter, J. L. (2008). Answers to 20 questions about interrater reliability and interrater agreement. Organizational Research Methods, 11(4), 815-852. doi:

$10.1177 / 1094428106296642$

Leithwood, K., \& Sun, J. (2012). The nature and effects of transformational school leadership. Educational Administration Quarterly, 48(3), 387-423. doi: 10.1177/0013161x11436268

List, C., \& Pettit, P. (2011). Group agency: The possibility, design, and status of corporate agents. Oxford Academic Press.

Ludema, J., Wilmot, T., \& Srivastva, S. (1997). Organizational Hope: Reaffirming the Constructive Task of Social and Organizational Inquiry. Humans Relations, 50, 1015-1052.

Luthans, F. (2002). The need for and meaning of positive organizational behavior. Journal of Organizational Behavior, 23(6), 695-706. doi: 10.1002/job.165

Luthans, F., \& Church, A.H. (2002). Positive organizational behavior: Developing and managing 
psychological strengths. Academy of Management Executive, 16(1), 57-72. doi: 10.2307/4165814

Luthans, F., Avey, J. B., Avolio, B. J., Norman, S. M., \& Combs, G. M. (2006). Psychological capital development: toward a micro-intervention. Journal of Organizational Behavior, 27(3), 387-393. doi: 10.1002/job.373

Luthans, F., Avolio, B.J., \& Avey, J.B. (2007). Psychological Capital Questionnaire [Measurement Instrument]. Retrieved from: http://www.mindgarden.com

Luthans, F., Avolio, B. J., Avey, J. B., \& Norman, S. M. (2007). Positive psychological capital: Measurement and relationship with performance and satisfaction. Personnel Psychology, 60(3), 541-572. doi: 10.1111/j.1744-6570.2007.00083.x

Luthans, F., Youseff, C. M., \& Avolio, B. J. (2007a). Psychological capital: Developing the

human competitive edge. New York, NY: Oxford University Press.

Luthans, F., Youssef, C. M., \& Avolio, B. J. (2007b). Psychological capital: Investing and developing positive organizational behavior. In D. Nelson \& C. L. Cooper (Eds.), Positive organizational behavior: Accentuating the positive at work (pp. 10-24). Thousand Oaks, CA: Sage.

Luthans, F., Avey, J. B., \& Patera, J. L. (2008). Experimental analysis of a web-based training intervention to develop positive psychological capital. Academy of Management Learning \& Education, 7(2), 209-221. doi: 10.5465/amle.2008.32712618

Luthans, F., Avey, J.B., Avolio, B.J., \& Peterson, S.J. (2010). The development and resulting performance impact of positive psychological capital. Human Resource Development Quarterly, 21(1), 41-67. doi 10.1002/hrdq.20034

Luthans, F., Youssef, C. M., \& Rawski, S. L. (2011). A tale of two paradigms: The impact of psychological capital and reinforcing feedback on problem solving and innovation. Journal of Organizational Behavior Management, 31(4), 333-350. doi: 10.1080/01608061.2011.619421

Lyubomirsky, S., Sheldon, K M., \& Schkade, D (2005). Pursuing happiness: The architecture of sustainable change. Review of General Psychology, 9(2), 1-46

MacKinnon, D. P., Lockwood, C. M., Hoffman, J. M., West, S. G., \& Sheets, V. (2002). A comparison of methods to test mediation and other intervening variable effects. Psychological Methods, 7(1), 83-104. doi: 10.1037/1082-989X.7.1.83

Masten, A. S., \& Reed, M. G. J. (2002). Resilience in development. In C. R. Snyder \& S. J. Lopez (Eds.), Handbook of positive psychology (pp. 74-88). Oxford, UK: Oxford University Press.

Mathe-Soulek, K., Scott-Halsell, S., Kim, S., \& Krawczyk, M. (2014). Psychological capital in the quick service restaurant industry: A study of unit-level performance. Journal of Hospitality E Tourism Research, 24. doi:10.1177/1096348014550923

Mathieu, J., Maynard, M. T., Rapp, T., \& Gilson, L. (2008). Team effectiveness 1997-2007: A review of recent advancements and a glimpse into the future. Journal of Management, 34(3), 410-476. doi: 10.1177/0149206308316061

Megeirhi, H., Kilic, H., Avci T., Afsar B. \& Abubakar, M. (2018). Does team psychological capital moderate the relationship between authentic leadership and negative outcomes: an investigation in the hospitality industry, Economic Research Ekonomska Istraživanja, 31(1), 927-945, doi: 10.1080/1331677X.2018.1442234

Morgan Roberts, L., Dutton, J., Spreitzer, G., Heaphy, E., \& Quinn, R. (2005). Composing the reflected bestself portrait: building pathways for becoming extraordinary in work organizations. Academy of Management Review, 30(4), 712-736.

Nesterkin, D. A., \& Ganster, D. C. (2015). The effects of nonresponse rates on group-level correlations. Journal of Management, 41(3), 789-807.. doi: 10.1177/0149206311433853

Nielsen, T. M., Hrivnak, G. A., \& Shaw, M. (2009). Organizational citizenship behavior and performance: A meta-analysis of group-level research. Small Group Research, 40(5), 555-577. doi: $10.1177 / 1046496409339630$ 
Norman, S., Luthans, B., \& Luthans, K. (2005). The proposed contagion effect of hopeful leaders on the resiliency of employees and organizations. Journal of Leadership \& Organizational Studies, 12(2), 55-64. doi: $10.1177 / 107179190501200205$

Ogunlade, J. O. (1979). Personality characteristics related to susceptibility to behavioral contagion. Social Behavior and Personality: An International Journal, 7(2), 205-208. doi: 10.2224/sbp.1979.7.2.205

Organ, D. W. (1988). Organizational citizenship behavior: The good soldier syndrome.

Lexington, MA: Lexington.

Organ, D. W., Podsakoff, P. M., \& Mackenzie, S. B. (2006). Organizational citizenship behavior: Its nature, antecedents, and consequences. Beverly Hills, CA: Sage.

Ostroff, C. (1992). The relationship between satisfaction, attitudes, and performance: An organizational level analysis. Journal of Applied Psychology, 77(6), 963-974

Peterson, S. J., Walumbwa, F. O., Byron, K., \& Myrowitz, J. (2009). CEO positive psychological traits, transformational leadership, and firm performance in high-technology start-up and established firms. Journal of Management, 35(2), 348-368. doi: 10.1177/0149206307312512

Peterson, S. J., Luthans, F., Avolio, B. J., Walumbwa, F. O., \& Zhang, Z. (2011). Psychological capital and employee performance: A latent growth modelling approach. Personnel Psychology, 64(2), 427-450. doi: 10.1111/j.1744-6570.2011.01215.x

Peterson, S. J., \& Zhang Z. (2011) Examining the relationships between top management team psychological characteristics, transformational leadership, and business unit performance. In M. A. Carpenter (Ed.), Handbook of research on top management teams (pp. 127-149). New York: Edward Elgar

Paterson, T., Luthans, F., \& Jeung, W. (2014). Thriving at work: Impact of psychological capital and supervisor support. Journal of Organizational Behavior, 35, 434-446. doi: 10.1002/job.1907

Podsakoff, P. M., MacKenzie, S. B., Lee, J.-Y., \& Podsakoff, N. P. (2003). Common method biases in behavioral research: A critical review of the literature and recommended remedies. Journal of Applied Psychology, 88(5), 879-903.

Podsakoff, P. M., MacKenzie, S. B., \& Podsakoff, N. P. (2012). Sources of method bias in social science research and recommendations on how to control it. Annual Review of Psychology, 63(1), 539-569. doi: doi:10.1146/annurev-psych-120710-100452

Preacher, K. J., \& Hayes, A. F. (2004). SPSS and SAS procedures for estimating indirect effects in simple mediation models. Behavior Research Methods, 36(4), 717-731.

Prussia, G. F., \& Kinicki, A. J. (1996). A motivational investigation of group effectiveness using socialcognitive theory. Journal of Applied Psychology, 81, 187-198.

Riggs, M. L., \& Knight, P. A. (1994). The impact of perceived group success-failure on motivational beliefs and attitudes: A causal model. Journal of Applied Psychology

79, 755-766.

Rego A., Owens, B., Yam, K., Bluhm, D., Pina e Cunha, M., Silard, A. Gonçalves, L, Martins, M., Volkmann A., \& Liu, W. (2017). Leader humility and team performance: exploring the mediating mechanisms of team PsyCap and task allocation effectiveness. Journal of Management, 20(10), 1-25. doi: $10.1177 / 0149206316688941$

Salas, E., Cooke, N. J., \& Rosen, M. A. (2008). On teams, teamwork, and team performance: Discoveries and developments. Human Factors: The Journal of the Human Factors and Ergonomics Society, 50(3), 540-547.

Salanova, M., Llorens, S., Cifre, E., \& Martínez, I. M. (2012). We need a hero! toward a validation of the healthy and resilient organization (HERO) model. Group \& Organization Management, 37(6), 785-822. doi:10.1177/1059601112470405

Satorra, A., \& Bentler, P. M. (2001). A scaled difference chi-square test statistic for moment structure analysis. Psychometrika, 66(4), 507-514. doi: 10.1007/BF02296192

Scheier, M. F., \& Carver, C. S. (1985). Optimism, coping, and health: Assessment and implications of 
generalized outcome expectancies. Health Psychology, 4(3), 219-247. doi: 10.1037/0278-6133.4.3.219

Schneider, B., Ehrhart, M. G., Mayer, D. M., Saltz, J. L., \& Niles-Jolly, K. (2005). Understanding organizationcustomer links in service settings. Academy of Management Journal, 48(6), 1017-1032. doi:

10.5465/amj.2005.19573107

Segerstrom, S. C. (2001). Optimism and attentional bias for negative and positive stimuli.

Personality and Social Psychology Bulletin, 27(10), 1334-1343. doi:

10.1177/01461672012710009

Seligman, M. E. (1990). Learned optimism. New York, NY: Simon \& Schuster.

Shamir, B., Zakay, E., Breinin, E., \& Popper, M. (1998). Correlates of charismatic leader behaviour in military units: Subordinates' attitudes, unit characteristics, and superiors' appraisals of leader performance. Academy of Management Journal, 41(4), 387-409. doi: 10.2307/257080

Silver, W. S., \& Bufanio, K. M. (1996). The impact of group efficacy and group goals on group task performance. Small Group Research, 27, 347-359.

Snyder, C. R., Harris, C., Anderson, J. R., Hollaran, S. A., Irving, L. M., Sigmon, S. T., et al. (1991). The will and the ways: Development and validation of an individual-differences measure of hope. Journal of Personality and Social Psychology, 60(4), 570-585. doi: 10.1037/0022-3514.60.4.570

Snyder, C. R. (2000). Handbook of hope: Theory, measures, and applications. San Diego, CA: Academic Press. Spink, K. S. (1990a). Collective efficacy in the sport setting. International Journal of Sport Psychology, 21, 380395.

Stadjkovic, A. D., Luthans, F., \& Slocum, J. W. (1998). Social cognitive theory and self-efficacy: Going beyond traditional motivational and behavioral approaches. Organizational Dynamics, 26(4), 62-74.

Stevens, R. J. (2004). Why do educational innovations come and go? What do we know? What can we do? Teaching and Teacher Education, 20(4), 389-396. doi:

10.1016/j.tate.2004.02.011

Sun T., Zhao X.W., Yang L.B., \& Fan L.H. (2012). The impact of psychological capital on job embeddedness and job performance among nurses: a structural equation approach. Journal of Advanced Nursing, 68(1), 69-79. doi: 10.1111/ j.1365-2648.2011.05715.x

Sweetman, D., Luthans, F., Avey, J. B., \& Luthans, B. C. (2011). Relationship between positive psychological capital and creative performance. Canadian Journal of Administrative Sciences, 28(1), 4-13. doi:

10.1002/cjas.175

Sy, T., Côté, S., \& Saavedra, R. (2005). The contagious leader: Impact of the leader's mood on the mood of group members, group affective tone, and group processes. Journal of Applied Psychology, 90(2), 295-305. doi: 10.1037/0021-9010.9 0.2.295

Tannenbaum, S. I., Mathieu, J. E., Salas, E., \& Cohen, D. (2012). Teams are changing: Are research and practice evolving fast enough? Industrial and Organizational Psychology, 5(1), 2-24. doi: 10.1111/j.17549434.2011.01396.x

Tekleab, G,. Quigley, R., \& Tesluk, P. (2009). A longitudinal study of team conflict, conflict management, cohesion, and team effectiveness. Group \& Organization Management, 34, 170-205.

Tsang, E., \& Kwan, E. (1999). Replication and theory development in organizational science: A critical realist perspective. Academy of Management Review, 24(4), 759-780. doi: 10.5465/amr.1999.2553252

Turner, N., Barling, J., \& Zacharatos, A. (2002). Positive psychology at work. In C. R. Snyder \& S. J. Lopez (Eds.), Handbook of positive psychology (pp.715-728). Oxford: Oxford University Press.

Vigoda-Gadot, E., Beeri, I., Birman-Shemesh, T., \& Somech, A. (2007). Group-level organizational citizenship behavior in the education system: A scale reconstruction and validation. Educational Administration Quarterly, 43(4), 462-493. doi: 10.1177/0013161x07299435

Wallace, M. (2001). Sharing leadership of schools through teamwork. Educational Management Administration E Leadership, 29(2), 153-167. doi: 10.1177/0263211x010292002 
Walumbwa, F. O., Peterson, S. J., Avolio, B. J., \& Hartnell, C. A. (2010). An investigation of the relationships among leader and follower psychological capital, service climate, and job performance. Personnel Psychology, 63(4), 937-963. doi: 10.1111/j.1744-6570.2010.01193.x

Watson, C., Chemers, M., \& Preiser, N. (2001). Collective efficacy: A multilevel analysis. Personality and Social Psychology Bulletin, 27, 1057-1068.

West, B. J., Patera, J. L., \& Carsten, M. K. (2009). Team level positivity: Investigating positive psychological capacities and team level outcomes. Journal of Organizational Behavior, 30(2), 249-267. doi: 10.1002/job.593

West, M. A., \& Wallace, M. (1991). Innovation in health care teams. European Journal of Social Psychology, 21(4), 303-315. doi: 10.1002/ejsp.2420210404

Williams, L. J., \& Anderson, S. E. (1991). Job satisfaction and organizational commitment as predictors of organizational citizenship and in-role behaviors. Journal of Management, 17(3), 601-617. doi: 10.1177/014920639101700305

Williams, P., Kern, M., \& Waters, L. (2015). A longitudinal examination of the association between psychological capital, perceptions of organizational virtuousness and work happiness in school staff. Psychology of Wellbeing, 5(5), 1-18

Williams, P., Kern, P., \& Waters, L. (2016). Exploring selective exposure and confirmation bias as processes underlying employee work happiness: An intervention study. Frontiers in Psychology, 7, 1-13. doi: 10.3389/fpsyg.2016.00878

Williams, P., Kern, P., \& Waters, L. (2017). The role and reprocessing of attitudes in fostering employee work happiness: An intervention study. Frontiers in Psychology, 8(28), 1-12. doi:10.3389/fpsyg.2017.00028

Woolley, L., Caza, A., \& Levy, L. (2011). Authentic leadership and follower development.

Journal of Leadership \& Organizational Studies, 18(4), 438-448. doi:

$10.1177 / 1548051810382013$

Xu, J., Liu Y., \& Chung B. (2017) Leader psychological capital and employee work engagement: The roles of employee psychological capital and team collectivism. Leadership \& Organization Development Journal, 38(7), 969-985. doi: 10.1108/LODJ-05-2016-0126

Yammarino, F. J., \& Atwater, L. E. (1993). Understanding self-perception accuracy: Implications for human resource management. Human Resource Management, 32(2\&3), 231-247. doi: 10.1002/hrm.3930320204

Zaccaro, S. J., Blair., V., Peterson, C., \& Zazanis, M. (1995). Collective efficacy. In J. E. Maddux (Ed.), Selfefficacy, adaptation, and adjustment: Theory, research, and application(pp. 305-328). New York, NY: Plenum Press. 